Marek ŚWIERCZYŃSKi, ŁUKaSZ ŻARnOWIEC

Uniwersytet Kardynała Stefana Wyszyńskiego w Warszawie

\title{
PRAWO WŁAŚCIWE DLA ODPOWIEDZIALNOŚCI ZA SZKODĘ SPOWODOWANĄ PRZEZ WYPADKI DROGOWE Z UDZIAŁEM AUTONOMICZNYCH POJAZDÓW
}

\section{WPROWADZENIE}

W rezolucji Parlamentu Europejskiego z 16 lutego 2017 r. zawierającej zalecenia dla Komisji Europejskiej w sprawie przepisów prawa cywilnego dotyczących robotyki ${ }^{1}$ stwierdzono, że wykorzystanie algorytmów sztucznej inteligencji wpłynie na wszystkie obszary transportu, zarówno indywidualnego, zbiorowego, jak i towarowego. Proces ten przyczyni się do rozwoju i upowszechnienia pojazdów autonomicznych. Wywrze także wpływ na reżim odpowiedzialności cywilnej.

Wykorzystanie autonomicznych pojazdów w transporcie powinno zwiększyć bezpieczeństwo w ruchu drogowym. Szacuje się, że około 90\% wypadków drogowych spowodowanych jest błędami ludzkimi². Wypadków drogowych nie da się jednak uniknąć. Co więcej, algorytmy sztucznej inteligencji sterujące pojazdami autonomicznymi będą musiały

1 Civil Law Rules on Robotics. European Parliament resolution of 16 February 2017 with recommendations to the Commission on Civil Law Rules on Robotics (2015/2103(INL), P8_TA(2017)0051 (dalej jako Rezolucja z 2017 r.).

2 Dane oparte na sprawozdaniu Komisji Europejskiej „Ratowanie życia: zwiększanie bezpieczeństwa samochodowego w UE” (COM(2016) 0787 final). 
w chwilach krytycznych, kiedy wypadku nie da się już uniknąć, podejmować decyzje dotyczące życia i zdrowia uczestników ruchu. Proces ten może się odbywać $\mathrm{z}$ udziałem lub bez udziału czynnika ludzkiego ${ }^{3}$.

Stopień autonomiczności pojazdów może być różny. Obok pojazdów całkowicie autonomicznych (brak kierowcy) występują pojazdy pozwalające kierowcy na przejęcie kontroli nad samochodem oraz wyposażone w systemy jedynie wspomagające kierowcę ${ }^{4}$. Wydaje się, że najmniej komplikacji prawnych wywołują wykorzystywane już obecnie samochody $\mathrm{z}$ aktywnym wspomaganiem, na przykład aktywny tempomat, asystent poruszania się w korkach, zaawansowany asystent pasa ruchu.

W celu ustalenia, kto ponosi odpowiedzialność, wymagane jest uwzględnienie zastosowanej technologii pod kątem stopnia autonomiczności decyzji oraz jej wpływu na zaistnienie zdarzenia ${ }^{5}$. Rozkład faktycznej odpowiedzialności zależy jednak od okoliczności konkretnego wypadku. Nie chodzi wyłącznie o odpowiedzialność kierującego czy samoistnego posiadacza pojazdu. W przypadku wypadków drogowych z udziałem autonomicznych pojazdów w grę może wchodzić ponadto odpowiedzialność producenta, wytwórcy części, importera, dystrybutora, sprzedawcy, programisty, dostawcy usług transportowych (np. taxi AI), usługodawcy internetowego (np. z powodu braku

3 A. CAssart, Aéronefs sans pilote, voitures sans conducteur: la destination plus importante que le voyage, [w:] L'intelligence artificielle et le droit, red. H. JACQUEMIN, A. De Streel, Bruxelles 2017, s. 319. Co do zakresu autonomii decyzyjnej sztucznej inteligencji por. szerzej N. NevejAns, Traité de droit et d'éthique de la robotique civile, Bordeaux 2017, s. 134-137.

4 Por. szerzej P. Stone, R. Brooks, E. Brynjolfsson, R. Calo, O. Etzioni, G. Hager, J. Hirschberg, S. Kalyanakrishnan, E. Kamar, S. Kraus, K. Leyton-Brown, D. Parkes, W. Press, A. Saxenian, J. Shah, M. Tambe, A. Teller, Artificial Intelligence and Life in 2030. One Hundred Year Study on Artificial Intelligence: Report of the 2015-2016 Study Panel, Stanford University, September 2016, https://ai100.stanford.edu/sites/default/files/ai100report10032016fnl_singles.pdf, s. 19, dostęp 9 stycznia 2019 r.

Por. J. Gurney, Sue my car not me: Products liability and accidents involving autonomous vehicles, "University of Illinois Journal of Law, Technology and Policy" 2/2013, s. 247-277; G. MARCHAND, R. LINDOR, The coming collision between autonomous vehicles and the liability system, «Santa Clara Law Review» 52/2012, s. 1321-1340. 
możliwości aktualizacji oprogramowania) ${ }^{6}$. Należy jednak pamiętać, że ocena odpowiedzialności nie może mieć charakteru abstrakcyjnego. Każdorazowo musi się ona odbywać w ramach określonego porządku prawnego, przy czym prawo właściwe dla odpowiedzialności każdego $\mathrm{z}$ wymienionych podmiotów będzie $\mathrm{z}$ reguły ustalane odrębnie.

Wskazanie prawa właściwego dla wypadków drogowych już obecnie nie jest łatwe ${ }^{7}$. Zagadnienie to jest regulowane w większości państw europejskich przez konwencję o prawie właściwym dla wypadków drogowych, która pochodzi z lat 70. XX w. i nie zawiera klauzul korekcyjnych. Jako podstawowy łącznik wykorzystano prawo miejsca wypadku. Od reguły tej przewidziano jednak wyjątki. Jednym $\mathrm{z}$ alternatywnych rozwiązań jest prawo miejsca rejestracji pojazdu. Powstaje pytanie, czy w kontekście autonomicznych samochodów rozwiązanie to można uznać za satysfakcjonujące. Obecny system kolizyjnoprawny wydaje się nadmiernie złożony w zakresie wypadków drogowych ${ }^{8}$. Naszym zdaniem obowiązywać powinny jednoznaczne i zrozumiałe dla poszkodowanego zasady ustalania prawa właściwego. Celem jest zwiększenie przewidywalności i pewności co do prawa właściwego. Wykorzystanie algorytmów sztucznej inteligencji w autonomicznych pojazdach zwiększa skalę problemu. Wywołuje komplikacje nie tylko w prawie materialnym ${ }^{9}$, lecz także w prawie prywatnym międzynarodowym ${ }^{10}$.

W niniejszym opracowaniu odpowiemy na następujące pytania badawcze. Po pierwsze, czy obowiązujące normy kolizyjne są dostosowane do specyfiki szkód wyrządzonych wskutek wypadków drogowych, spowodowanych przez autonomiczny pojazd. Po drugie, jeśli przepisy nadają się do zastosowania, to czy nie są zbyt złożone i skomplikowane,

6 Por. J. Gurney, Sue my car..., s. 258-266.

Por. Rezolucja z 2017 r.

8 Por. W. Klyta, [w:] System Prawa Prywatnego. Prawo prywatne międzynarodowe, red. M. Pazdan, Warszawa 2015, s. 883.

9 Por. szerzej R. Akerkar, Introduction to Artificial Intelligence, [w:] Artificial Intelligence for Business, red. R. Akerkar, Cham 2019; T. Pietrzy kowski, Personhood Beyond Humanism Animals, Chimeras, Autonomous Agents and the Law, Cham 2018.

10 Por. B. Ввоżeк, The Troublesome 'Person', [w:] Legal Personhood: Animals, Artificial Intelligence and the Unborn, red. V. Kurki, T. Pietrzy kowski, Cham 2017, s. 3-13. 
a w szczególności czy utrudniają sytuację prawną poszkodowanemu w dochodzeniu swoich roszczeń i czy w związku z tym nie należałoby ich zmienić, na przykład uprościć. Po trzecie, jakie są rekomendowane rozwiązania, gdy chodzi o zmianę obowiązujących przepisów kolizyjnoprawnych dotyczących odpowiedzialności powstającej w przypadku wypadków drogowych (z udziałem autonomicznych pojazdów).

\section{BRAK PEŁNEGO UJEDNOLICENIA PRZEPISÓW KOLIZYJNYCH W ZAKRESIE WYPADKÓW DROGOWYCH}

Ujednolicenie norm kolizyjnych w zakresie odpowiedzialności pozaumownej dokonane przez rozporządzenie (WE) nr 864/2007 Parlamentu Europejskiego i Rady (Rzym II) nie jest pełne ze względu na przystąpienie niektórych państw członkowskich UE, w tym Polski, do konwencji międzynarodowych regulujących wybrane zagadnienia odmiennie. Zgodnie $\mathrm{z}$ art. 28 rozporządzenia Rzym II pozostaje ono bez uszczerbku dla stosowania międzynarodowych konwencji, chyba że konwencje zostały zawarte wyłącznie między dwoma lub więcej państwami członkowskimi UE. Zatem postanowienia umów międzynarodowych, których stroną w chwili przyjęcia rozporządzenia są państwa trzecie, zachowują pierwszeństwo przed zunifikowanymi normami kolizyjnymi rozporządzenia ${ }^{11}$. Zarówno konwencja haska o prawie właściwym dla wypadków drogowych z 1971 r. ${ }^{12}$, jak i konwencja haska o odpowiedzialności za produkt niebezpieczny z 1973 r. mają więc pierwszeństwo przed rozporządzeniem Rzym $\mathrm{II}^{13}$. W konsekwencji art. 28 rozporządzenia

11 Por. J. Pazdan, Rozporządzenie Rzym II - nowe wspólnotowe unormowanie właściwości prawa dla zobowiązań pozaumownych, "Problemy Prawa Prywatnego Międzynarodowego» 4/2009, s. 15-17; C. NAGy, The Rome II Regulation and Traffic Accidents: Uniform Conflict Rules with some Room for forum shopping - how so?, "JPIL» 6.1/2010, s. 93.

12 T. Graziano, Cross-border Traffic Accidents in the EU - the Potential Impact of Driverless Cars, European Parliament - Directorate-General for Internal Policies of the Union, Brussels 2016 (dalej jako T. Graziano, Report 2016).

13 Por. M. Szpunar, K. PacuŁa, [w:] Prawo prywatne międzynarodowe. Komentarz, red. M. PAZdAn, Warszawa 2018, s. 1028. 
Rzym II pozwala na współistnienie w odniesieniu do omawianej materii różnych zestawów norm międzynarodowego prawa prywatnego w UE. Tymczasem wykazują one daleko idące różnice w zakresie zasad ustalania prawa właściwego. Sytuację komplikuje dodatkowo fakt, że spośród państw członkowskich UE nie wszystkie pozostają związane rozporządzeniem Rzym II. Zgodnie z motywem 40 preambuły oraz art. 1 ust. 4 rozporządzenia Dania nie uczestniczy w przyjęciu rozporządzenia, nie jest nim związana i nie stosuje go, a w konsekwencji nie jest do jego celów uznawana za państwo członkowskie. Zważywszy dodatkowo, że w państwie tym nie obowiązuje zarówno konwencja haska z 1971 r., jak i konwencja haska z 1973 r., poszukiwanie prawa właściwego w interesującej nas kategorii spraw odbywa się tam - tak jak dotychczas - za pośrednictwem nieujednoliconych, krajowych norm kolizyjnych forum ${ }^{14}$.

W rezultacie w sprawach dotyczących odpowiedzialności wynikającej z wypadków drogowych oraz w sprawach dotyczących odpowiedzialności za produkt, w poszczególnych państwach członkowskich może znaleźć zastosowanie różne prawo merytoryczne. Uproszczenie systemu ustalenia prawa właściwego dla wypadków drogowych zwiększyłoby w tej sytuacji pewność prawną i ograniczyłoby możliwość wystąpienia niekorzystnego zjawiska forum shopping ${ }^{15}$. Polega ono na świadomym wykorzystywaniu różnic w prawie prywatnym międzynarodowym poszczególnych państw, tak aby w ramach możliwości wynikających z norm określających jurysdykcję krajową, poprzez wytoczenie powództwa w wybranym $\mathrm{z}$ nich, uzyskać zastosowanie oczekiwanych norm merytorycznych. W analizowanej kategorii spraw o tym, jakie prawo znajdzie zastosowanie, zadecyduje w szczególności to, czy powództwo

14 M. Krzymuski, Wybór prawa właściwego dla pozaumownej odpowiedzialności cywilnej wynikającej z wypadków drogowych, [w:] Znad granicy ponad granicami. Księga dedykowana Profesorowi Dieterowi Martiny, Warszawa 2014, s. 135.

15 W kwestii ryzyka forum shopping pod rządami rozporządzenia Rzym II w związku z obowiązywaniem w części państw członkowskich UE konwencji haskich z $1971 \mathrm{r}$. i 1973 r. por. J. Von HeIn, Of Older Siblings and Distant Cousins: The Contribution of the Rome II Regulation to the Communitarisation of Private International Law, «RabelsZ» 73/2009, s. 474 . 
poszkodowanego rozpoznawane jest przez sądy państwa konwencyjnego, czy też jednego z państw, które nie jest stroną danej konwencji haskiej.

Dla poszkodowanego w wypadku drogowym, w którym brały udział autonomiczne technologie, może być trudne, kosztowne i czasochłonne zidentyfikowanie dokładnej przyczyny wypadku, dostarczenie dowodu na tę przyczynę, a w konsekwencji podjęcie decyzji, przeciw komu skierować roszczenie odszkodowawcze. Czy będzie to posiadacz samochodu lub jego ubezpieczyciel czy producent samochodu lub części? Może to być również dostawca usług internetowych, z którymi łączy się pojazd autonomiczny. Nie oznacza to jednak konieczności uprzywilejowania poszkodowanego w prawie prywatnym międzynarodowym. Optymalne normy kolizyjne powinny być zbalansowane i uwzględniać również uzasadnione interesy osoby, której przypisuje się odpowiedzialność. Argument ten nabiera szczególnego znaczenia tam, gdzie prawdopodobieństwo poniesienia odpowiedzialności stanowi swoistą cenę za innowacyjność wprowadzanych przez dany podmiot rozwiązań technologicznych, jak ma to miejsce w przypadku koncepcji odpowiedzialności za produkt. Obciążenie wyłącznie przedsiębiorcy ryzykiem dokonywanych zmian także w płaszczyźnie metod wyznaczania prawa właściwego dla jego potencjalnej odpowiedzialności mogłoby zniechęcać do innowacji, co bez wątpienia nie leży w interesie społecznym.

Jak wskazuje się wprost w motywie 20 preambuły do rozporządzenia Rzym II, w odniesieniu do odpowiedzialności za produkt norma kolizyjna powinna zapewniać sprawiedliwy rozkład ryzyka występującego nieodłącznie w nowoczesnym, technologicznie zaawansowanym społeczeństwie, ochronę zdrowia konsumentów, stymulowanie innowacji, zagwarantowanie niezakłóconej konkurencji oraz ułatwianie handlu. Przyjęte rozwiązanie powinno co najmniej umożliwiać zorientowanie się z góry co do prawa właściwego do oceny ewentualnej odpowiedzialności za powstałą szkodę, a w konsekwencji ocenić i skalkulować wynikające stąd ryzyko ${ }^{16}$.

16 Por. Hamburg Group for Private International Law, Comments on the European Commission's Draft Proposal for a Council Regulation on the Law Applicable to 
Nie sposób syntetycznie omówić wszystkich norm kolizyjnych znajdujących potencjalnie zastosowanie w omawianej kategorii przypadków. Przykładem jest odpowiedzialność za szkody wyrządzone działaniami lub zaniechaniami przy wykonywaniu władzy publicznej, które doprowadziły do wypadku, w którym uczestniczyły pojazdy autonomiczne. Działania te (lub zaniechania) mogą dotyczyć infrastruktury technicznej niezbędnej do działania pojazdów autonomicznych. Są związane ze współpracą transgraniczną państw (por. prace grupy roboczej EKG ONZ /WP.29/). Aby pojazdy autonomiczne mogły poruszać się po drogach UE, konieczne jest ustalenie wspólnych standardów w budowie infrastruktury oraz komunikowania się pojazdów. Tymczasem materia odpowiedzialności za acta iure imperii wyłączona została poza zakres przedmiotowy rozporządzenia Rzym II w jego art. 1 ust. 1 zd. 2, a w konsekwencji leży w gestii krajowych norm kolizyjnych poszczególnych państw. Według art. 35 ustawy z 2011 r. odpowiedzialność cywilna za działania i zaniechania organów wykonujących $w$ danym państwie władzę publiczną podlega prawu tego państwa. Niestety, jest to regulacja tylko wycinkowa.

Ponadto, przy dokonywaniu oceny odpowiedzialności sądy pod uwagę powinny wziąć, jako element stanu faktycznego, przepisy obowiązujące w miejscu zdarzenia. Wpływają one na ocenę, nawet jeżeli prawem właściwym jest prawo obce (por. art. 16 Rzym II oraz art. 7 konwencji z 1971 r.). Warto zauważyć, że Polska ratyfikowała Konwencję o ruchu drogowym, sporządzoną w Wiedniu 8 listopada 1968 r., jak również Konwencję o znakach i sygnałach drogowych, sporządzoną w Wiedniu 8 listopada 1968 r. Przepisy obu umów międzynarodowych nie uwzględniają jeszcze w zadowalającym stopniu pojazdów w pełni autonomicznych. Zapewne ulegnie to jednak zmianie w niedalekiej przyszłości.

Przedstawiony powyżej złożony charakter szkód wyrządzonych przez autonomiczne pojazdy może zachęcać sądy do sięgania do reguł

Non-Contractual Obligations, s. 15. Odnośnie do znaczenia kryterium przewidywalności w prawie prywatnym międzynarodowym - por. T. PAJOR, Comments on a preliminary draft proposal for a Council Regulation on the law applicable to non-contractual obligations, Łódź 2002, s. 9. 
korekcyjnych (por. art. 4 ust. 2 bądź art. 5 ust. 2 rozporządzenia Rzym II) w celu uzasadnienia właściwości prawa obowiązującego w siedzibie sądu (lex fori). Nie wydaje się to uzasadnione. Proponowane rozwiązania przedstawimy w końcowej części niniejszego opracowania.

\section{MOdEL KOLIZYJNOPRAWNY KONWENCJI HASKIEJ Z 1971 R.}

Konwencja haska o prawie właściwym dla wypadków drogowych z 4 maja 1971 r. została ratyfikowana przez Polskę ${ }^{17}$, w stosunku do której obowiązuje od dnia 28 maja 2002 r. Konwencja ta - zgodnie z zasadą uniwersalizmu - znajduje zastosowanie nawet wtedy, gdy prawo właściwe nie jest prawem państwa konwencyjnego ${ }^{18}$ i to niezależnie od spełnienia warunku kolizyjnoprawnej wzajemności (art. 11 zd. 2). W kontekście pojazdów autonomicznych należy podkreślić, że konwencji nie stosuje się do odpowiedzialności producentów, sprzedawców i naprawiających pojazdy (art. 2 pkt 1). Pojęcia te rozumieć należy przy tym szeroko, zakresem ich obejmując także producentów, sprzedawców oraz naprawiających części ${ }^{19}$. Wiele przemawia za tym, by w identyczny sposób postępować także i tam, gdzie nie chodzi o część w fizycznym, materialnym tego słowa znaczeniu, lecz o algorytmy sztucznej inteligencji

17 Ustawa z 5 lipca 2001 r. o ratyfikowaniu Konwencji o prawie właściwym dla wypadków drogowych ogłoszona została w Dz. U. z 2001 r. Nr 90, poz. 993, natomiast sam tekst konwencji w tłumaczeniu na język polski - w Dz. U. z 2003 r. Nr 63, poz. 585. Należy pamiętać, że w świetle art. 21 konwencji z 1971 r. charakter autentyczny mają wyłącznie jej teksty spisane w języku angielskim oraz francuskim. Stąd polskojęzyczne tłumaczenie opublikowane w Dzienniku Ustaw nie ma mocy wiążącej, stanowiąc jedynie instrument pomocniczy ułatwiający zastosowanie konwencji w jednym z języków oryginalnych - por. W. KLYTA, op. cit., s. 884, przyp. 783.

18 Wedle stanu na dzień 28 grudnia 2018 r. konwencja obowiązuje w 21 państwach, tj.: Austrii, Białorusi, Belgii, Bośni i Hercegowinie, Chorwacji, Republice Czeskiej, Macedonii, Francji, Litwie, Łotwie, Luksemburgu, Czarnogórze, Maroku, Holandii, Polsce, Serbii, Słowacji, Słowenii, Hiszpanii, Szwajcarii, Ukrainie; dane dostępne na stronie: https://www.hcch.net/en/instruments/conventions/status-table/?cid=81, dostęp: 9 stycznia $2019 \mathrm{r}$.

19 W. KLYta, op. cit., s. 891. 
służące do sterowania autonomicznymi funkcjami pojazdu, wykorzystane w programowaniu jego podzespołów.

Wśród wyłączeń spod omawianego zakresu zastosowania konwencji warto ze względu na przedmiot niniejszego opracowania wymienić także odpowiedzialność właściciela lub innej osoby odpowiedzialnej za utrzymanie drogi otwartej dla ruchu lub za bezpieczeństwo jej użytkowników (art. 2 pkt 2), roszczenia regresowe pomiędzy osobami ponoszącymi odpowiedzialność (art. 2 pkt 4), a także roszczenia regresowe i subrogację towarzystw ubezpieczeniowych (art. 2 pkt 5).

We wszystkich tych sprawach prawa właściwego poszukiwać należy za pośrednictwem miarodajnych norm kolizyjnych obowiązujących w siedzibie forum ${ }^{20}$. Z perspektywy sądu polskiego oznacza to konieczność sięgnięcia do postanowień rozporządzenia Rzym II, natomiast w sprawach tam nieuregulowanych (np. aktualne choćby w kontekście odpowiedzialności za utrzymanie dróg publicznych i bezpieczeństwo ich użytkowników wyłączenie odnoszące się do acta iure imperii) - do norm kolizyjnych zawartych w ustawie z 2011 r.

Konwencja z założenia służyć ma wyznaczeniu prawa właściwego dla pozaumownej odpowiedzialności cywilnej wynikającej z wypadków drogowych (art. 1). System prawny wskazany za pośrednictwem zawartych w niej norm kolizyjnych zakresem swego zastosowania nie obejmie zatem ewentualnych roszczeń powstałych z związku z wypadkiem z tytułu istniejącego już wcześniej między stronami stosunku obligacyjnego. $\mathrm{O}$ ich istnieniu i kształcie orzekać należy na podstawie przepisów prawa wskazanego za pośrednictwem norm kolizyjnych forum miarodajnych dla zobowiązań umownych ${ }^{21}$. W przypadku sądów państw członkowskich UE, z wyjątkiem Danii, będą to normy zawarte w przepisach rozporządzenia Parlamentu Europejskiego i Rady

20 T. Graziano, Das auf außervertragliche Schuldverhältnisse anzuwendende Recht nach Inkrafttreten der Rom II - Verordnung, «RabelsZ»73/2009, s. 26; A. Dickinson, The Rome II Regulation: The law applicable to non-contractual obligations, Oxford 2008, s. 360; A. Halfmeier, N. Sonder, [w:] Rome Regulations: Commentary on the European Rules of the Conflict of Laws, red. G. Calliess, Alphen aan den Rijn 2011, s. 642 .

${ }^{21}$ W. Klyta, op. cit., s. 885. 
nr 593/2008 z 17 czerwca 2008 r., dotyczącego prawa właściwego dla zobowiązań umownych (Rzym I) ${ }^{22}$. W związku ze specyfiką stosunków z zakresu transportu międzynarodowego należy jednak liczyć się $\mathrm{w}$ tym obszarze z pierwszeństwem jednolitych norm merytorycznych zawartych w konwencjach międzynarodowych ${ }^{23}$.

$\mathrm{Z}$ perspektywy prawa prywatnego międzynarodowego obowiązującego w siedzibie sądu rozstrzygać należy także o dopuszczalności ewentualnego zbiegu norm kolizyjnych miarodajnych dla zobowiązań umownych i pozaumownych oraz sposobie postępowania w przypadku jego wystąpienia ${ }^{24}$.

Wypadek drogowy w rozumieniu konwencji haskiej oznacza wypadek, w którym uczestniczy jeden lub kilka pojazdów z napędem silnikowym lub bez napędu, wiążący się z ruchem na drodze publicznej, na terenie ogólnodostępnym lub na terenie prywatnym dostępnym dla niektórych osób (art. 1 zd. 2). Samo pojęcie wypadku - pomimo że kluczowe dla wyznaczenia zakresu zastosowania konwencji oraz wskazania na jej podstawie prawa właściwego - nie zostało natomiast zdefiniowane $\mathrm{w}$ jej postanowieniach. W doktrynie zaproponowano, by za wypadek drogowy w rozumieniu konwencji uznawać nagłe, wywołane zewnętrzną przyczyną zdarzenie, wynikłe przy udziale co najmniej jednego pojazdu, prowadzące do szkód na osobach i rzeczach ${ }^{25}$.

Podobnie jak rozporządzenie Rzym II, także konwencja stoi na stanowisku przeciwnym odesłaniu. Wskazanie na prawo właściwe ze strony ujednoliconych norm kolizyjnych odnosi się zatem wyłącznie do regulacji merytorycznej danego porządku prawnego.

Co do zasady prawem właściwym dla pozaumownej odpowiedzialności cywilnej z tytułu wypadku drogowego jest w świetle postanowień

22 Dz. Urz. UE 2008 L 177/6, sprostowanie - Dz. Urz. UE 2009 L 309/87.

23 Co do ich znaczenia oraz stosunku względem norm kolizyjnych zawartych w rozporządzeniu Rzym I, a także wykazu najistotniejszych z nich por. M. ŚwIERCzYŃsKI, Ł. Żarnowiec, [w:] Prawo prywatne międzynarodowe. Komentarz, red. M. Pazdan, Warszawa 2018, s. 652-653 oraz 659-660.

24 W. Klyta, op. cit., s. 885.

25 Ibidem, s. 887-888; por. M. Jagielska, [w:] Prawo prywatne międzynarodowe. Komentarz, red. M. PAzDAN, Warszawa 2018, s. 1043. 
konwencji haskiej z 1971 r. prawo państwa, w którym nastąpił wypadek (art. 3).

Liczne odstępstwa od tej zasady przewiduje jednak art. 4 konwencji (przedstawiamy wersję stanowiącą poprawne, odmienne od oficjalnego, tłumaczenie przepisów na język polski).

1. Jeżeli w wypadku uczestniczy tylko jeden pojazd, który jest zarejestrowany w państwie innym niż to, w którym nastąpił wypadek, do odpowiedzialności stosuje się prawo państwa rejestracji: a) wobec kierowcy, posiadacza, właściciela i innej osoby mającej prawo do pojazdu, niezależnie od jej miejsca zwykłego pobytu, b) wobec ofiary będącej pasażerem, jeżeli jej miejscem zwykłego pobytu jest państwo inne niż to, w którym nastąpił wypadek, c) wobec ofiary znajdującej się poza pojazdem na miejscu wypadku, jeżeli miała miejsce stałego pobytu w państwie rejestracji. Jeżeli jest wiele ofiar, określa się prawo właściwe oddzielnie dla każdej $\mathrm{z}$ nich.

2. Jeżeli w wypadku uczestniczy wiele pojazdów, postanowienia pkt 1 stosuje się tylko wtedy, gdy wszystkie pojazdy są zarejestrowane w tym samym państwie.

3. Jeżeli w wypadku uczestniczy wiele osób znajdujących się poza pojazdem lub pojazdami na miejscu wypadku i mogą być one odpowiedzialne, postanowienia pkt 1 oraz pkt 2 stosuje się tylko wtedy, gdy wszystkie te osoby mają miejsca zwykłego pobytu w państwie rejestracji. Podobnie należy postępować, gdy osoby te są również ofiarami wypadku.

Wedle art. $6 \mathrm{w}$ przypadku pojazdu niezarejestrowanego lub zarejestrowanego w kilku państwach prawo państwa, w którym pojazdy te stale stacjonują, zastępuje prawo państwa rejestracji. To samo stosuje się, jeżeli ani właściciel, ani posiadacz, ani kierowca pojazdu nie mają w czasie wypadku miejsca stałego pobytu w państwie rejestracji.

Jak już wcześniej wskazano, niezależnie od prawa właściwego przy określaniu odpowiedzialności bierze się pod uwagę przepisy o bezpieczeństwie ruchu na drogach obowiązujące w miejscu i czasie wypadku (art. 7). 
Mimo że konwencja nie wypowiada się wprost w kwestii wyboru prawa właściwego dla odpowiedzialności z tytułu wypadków drogowych, zarówno w doktrynie ${ }^{26}$, jak i w orzecznictwie sądów ${ }^{27}$ dominuje stanowisko przychylne wyborowi następczemu ${ }^{28}$. O jego dopuszczalności oraz przesłankach ważności proponuje się - w braku regulacji konwencyjnej - rozstrzygać z perspektywy kolizyjnej legis fori, zatem w państwach członkowskich UE: na podstawie art. 14 rozporządzenia Rzym II ${ }^{29}$. Prawo wybrane miałoby w takim wypadku pierwszeństwo, wyłączając zastosowanie norm kolizyjnych konwencji operujących łącznikami obiektywnymi.

\section{Model KolizyjNOPRAWNy KONWENCJI HASKIEJ Z 1973 R. W PORÓWNANIU Z ROZPORZĄDZENIEM RZYM II}

Proces ustalenia prawa właściwego dla odpowiedzialności za szkodę wyrządzoną przez produkt w państwach członkowskich UE kształtuje się niejednolicie. W konsekwencji, w zależności od siedziby sądu

26 H. HoYeR, Haager Straßenverkehrsübereinkommen und Rechtswahl der Parteien, «ZfRV» 1991, s. 341; G. KegeL, [w:] G. KegeL, K. SCHURIG, Internationales Privatrecht, München 2000, s. 645; A. Halfmeier, N. Sonder, [w:] Rome Regulations: Commentary on the European Rules of the Conflict of Laws, red. G. CALliess, Alphen aan den Rijn 2011, s. 642; H. OfNer, Die Rom II - Verordnung - Neues Internationales Privatrecht für außervertragliche Schuldverhältnisse in der Europäischen Union, «ZfRV»1/2081, s. 22; M. KRZYMUSKI, op. cit., s. 150; W. KLYTA, op. cit., s. 909. Ostrożnie jednak w tej kwestii de lege lata: J. Von Hein, Article 4 and Traffic Accidents, [w:] The Rome II Regulation on the Law Applicable to Non-Contractual Obligations, red. J. Ahern, W. Binchy, Leiden-Boston 2009, s. 171. Przeciwni dopuszczalności wyboru są natomiast autorzy szwajcarscy - por. A. Rufener, H. Honsell, N.P. Vogt, A.K. Schnyder, S.V. Berrti, [w:] Basler Kommentar. Internastionales Privatrecht, Basel 2007, s. 1005.

${ }^{27}$ OGH, orzeczenie z 26 stycznia 1995 r., 2 Ob. 11/94, tekst dostępny na stronie: http://bit.ly/zp19_2_swierczynskil, dostęp: 9 stycznia 2019 r.

28 Na praktyczne znaczenie w odniesieniu do wypadków drogowych głównie tej właśnie postaci wyboru zwracają uwagę T. Graziano, op. cit., s. 27, oraz J. Von HeIn, op. cit., s. 170.

29 H. Ofner, op. cit., s. 22; J. Von Hein, Europäisches..., s. 32; J. Von Hein, Of Older Siblings..., s. 492; W. KLyta, op. cit., s. 909. 
orzekającego, w tym samym stanie faktycznym zastosowanie może znaleźć prawo innego państwa. Negatywnych skutków zjawiska forum shopping nie likwiduje niestety w pełni unifikacja norm merytorycznych w obrębie Unii. W państwach członkowskich normy materialne z zakresu odpowiedzialności za szkodę wyrządzoną przez produkt niebezpieczny zostały tylko częściowo ujednolicone na podstawie dyrektywy 85/374/EWG. Harmonizacja prawa materialnego państw członkowskich nie jest kompletna. Warto też zauważyć, że dyrektywa - co szczególnie istotne w kontekście skutków użycia pojazdów autonomicznych - nie reguluje odpowiedzialności za szkodę wyrządzoną przez produkt o charakterze niematerialnym (np. programy komputerowe), jak również szkód wyrządzonych w ramach świadczenia usług.

Analizę toku postępowania przy poszukiwaniu prawa właściwego dla ewentualnej odpowiedzialności producenta (lub sprzedawcy czy importera) pojazdu autonomicznego uczestniczącego w wypadku należy rozpocząć od przypomnienia, że ze względu na wyłączenie przyjęte w art. 2 pkt 1 konwencji haskiej z 1971 r., zawarte w niej normy kolizyjne nie są miarodajne dla omawianej tu kategorii przypadków. Rozwiązanie to ocenić należy pozytywnie nie tylko w związku z trudnościami, jakie jego brak powodowałby na styku z postanowieniami konwencji haskiej z 1973 r., lecz przede wszystkim z uwagi na specyfikę problemów towarzyszących odpowiedzialności wspomnianych osób, a w konsekwencji także wartości i racji wymagających rozważenia przy jej uregulowaniu, zarówno w płaszczyźnie merytorycznoprawnej, jak i kolizyjnej. Zatem prawo właściwe dla odpowiedzialności producenta (lub sprzedawcy czy importera) pojazdu autonomicznego należy ustalać na podstawie odrębnych norm kolizyjnych forum ${ }^{30}$. Także w przypadku terytorium UE o ich pochodzeniu i kształcie zadecyduje jednak siedziba sądu orzekającego.

I tak, w niektórych spośród państw członkowskich $\mathrm{UE}^{31}$ obowiązuje konwencja haska z 2 października 1973 r. o prawie właściwym dla odpo-

\footnotetext{
30 A. Dickinson, op. cit., s. 360.

31 Należą do nich: Chorwacja, Finlandia, Francja, Luksemburg, Holandia, Słowenia, Hiszpania - stan na 27 grudnia 2018 r., według danych zamieszczonych na stronie internetowej Haskiej Konferencji Prawa Prywatnego Międzynarodowego - https:// www.hcch.net/en/instruments/conventions/status-table/?cid=84.
} 
wiedzialności za produkt ${ }^{32}$. Z uwagi na treść art. 28 ust. 1 rozporządzenia Rzym II zawarte w niej normy kolizyjne, w zakresie regulowanych nimi spraw, mają tam pierwszeństwo przed miarodajnymi dla odpowiedzialności za produkt postanowieniami rozporządzenia ${ }^{33}$. Wyłączenie to nie jest jednak zupełne. Nie odnosi się bowiem do spraw wyjętych spod zakresu zastosowania konwencji. Zgodnie z art. 1 ust. 2 nie dotyczy ona natomiast ewentualnych roszczeń między osobą poszkodowaną a podmiotem pociągniętym do odpowiedzialności, jeśli prawo własności bądź uprawnienie do używania produktu przeniesione zostało między tymi osobami. Nie odnosi się również do prawa właściwego do oceny roszczeń regresowych, subrogacji czy dopuszczalności wystąpienia przez poszkodowanego $\mathrm{z}$ actio directa przeciwko ubezpieczycielowi. W tym zakresie zastosowanie znajdą miarodajne normy kolizyjne rozporządzenia Rzym II ${ }^{34}$.

System ustalania prawa właściwego na podstawie konwencji jest bardzo skomplikowany, co stanowi podstawowy zarzut formułowany wobec jej postanowień. W rezultacie niewiele państw podpisało konwencję, a jeszcze mniej ją ratyfikowało. Poza wymienionymi już wcześniej państwami członkowskimi UE, konwencja obowiązuje jedynie w: Norwegii, Serbii, Czarnogórze i Macedonii ${ }^{35}$.

32 Tekst dostępny m.in. w «RabelsZ» 37/1973, s. 594.

33 Por. C. Di Meglio, C. Coslin, EC Regulation on law applicable to non-contractual obligations: Will Rome II ever be applicable to product liability claims in France?, «European Product Liability Review» 12/2007, s. 8-10, które zwracają uwagę na ryzyko wynikających stąd komplikacji, w tym niebezpieczeństwo zjawiska forum shopping, w odniesieniu do odpowiedzialności za produkt. Tak też: G. GARrIGA, Relationships between "Rome II" and Other International Instruments. A Commentary on Article 28 of The Rome II Regulation, "YPIL» 9/2007, s. 142-143; T. GRAZIANO, Le nouveau droit international privé communautaire en matière de responsabilitè extracontractuelle, «RCDIP» 8-9/2008, s. 484; IDEM: Das auf außervertragliche..., s. 44.

34 R. Plender, M. Wilderspin, The European Private International Law of Obligations, London 2009, s. 563; Ł. Żarnowiec, [w:] System Prawa Prywatnego. Prawo prywatne międzynarodowe, red. M. PAzdan, Warszawa 2015, s. 775-776; P. MACHNIKowski, [w:] Prawo prywatne międzynarodowe. Komentarz, red. M. PAzDAn, Warszawa 2018, s. 907.

35 Status konwencji jest dostępny na stronie https://www.hcch.net/en/instruments/ conventions/status-table/?cid=84, dostęp: 9 stycznia 2019 r. 
Zawarte w niej normy kolizyjne nie są oparte na jednym łączniku, lecz na ich grupie wspólnie wskazującej dany system prawny. Przyjęto, że żaden pojedynczy łącznik nie gwarantuje osiągnięcia właściwego rezultatu kolizyjnoprawnego.

W myśl postanowień konwencji prawem właściwym do oceny odpowiedzialności za szkodę wyrządzoną przez produkt niebezpieczny jest prawo państwa:

1. zwykłego pobytu osoby bezpośrednio poszkodowanej, o ile w państwie tym mieści się również główna siedziba handlowa podmiotu pociągniętego do odpowiedzialności bądź miejsce nabycia produktu przez osobę bezpośrednio poszkodowaną (art. 5);

2. w którym szkoda powstała, o ile w państwie tym mieści się równocześnie miejsce zwykłego pobytu osoby bezpośrednio poszkodowanej, główna siedziba handlowa podmiotu pociągniętego do odpowiedzialności, miejsce, w którym produkt został nabyty przez osobę bezpośrednio poszkodowaną (art. 4), albo

3. w braku powiązań opisanych powyżej - prawo państwa głównej siedziby handlowej osoby pociągniętej do odpowiedzialności, chyba że powód wyprowadza swoje roszczenie z przepisów prawa państwa, w którym powstała szkoda (art. 6).

Jednakże mimo spełnienia kryteriów wynikających z postanowień art. 4-6 właściwość prawa miejsca wystąpienia szkody bądź prawa miejsca zwykłego pobytu poszkodowanego jest wyłączona, jeżeli podmiot pociągnięty do odpowiedzialności wykaże, że nie mógł - rozsądnie rzecz biorąc - przewidzieć, że dany produkt względnie inny jego produkt tego samego typu będzie dostępny w danym państwie w obrocie handlowym (art. 7).

Niewątpliwą zaletą konwencji jest natomiast wprowadzenie w art. 8 przykładowego katalogu spraw mieszczących się w zakresie statutu odpowiedzialności za szkodę wyrządzoną przez produkt. Obejmuje on w szczególności: podstawę i zakres odpowiedzialności, podstawy jej wyłączenia, jej ograniczenia i podział, rodzaje szkód podlegające naprawieniu, postać i rozmiar odszkodowania, dopuszczalność przelewu i dziedziczenia roszczeń odszkodowawczych, podmioty uprawnione do odszkodowania, odpowiedzialność zwierzchnika lub pracodawcy 
za wykonawcę czynności lub pracownika, reguły rozkładu ciężaru dowodu, o ile należą one do regulacji odpowiedzialności odszkodowawczej, a także regulację przedawnienia lub innych terminów ograniczających prawo do naprawienia szkody ${ }^{36}$.

W państwach członkowskich UE, które nie przystąpiły do konwencji z 1973 r., wskazanie prawa właściwego do oceny odpowiedzialności za szkodę wyrządzoną przez produkt następuje za pośrednictwem norm kolizyjnych zawartych w przepisach rozporządzenia Rzym II. Kryterium, które należy brać tutaj pod uwagę w pierwszej kolejności, jest zgodna wola stron. Artykuł 14 rozporządzenia dopuszcza bowiem wybór prawa także w odniesieniu do zobowiązania pozaumownego wynikającego ze szkody wyrządzonej przez produkt ${ }^{37}$. Zgodnie z treścią wyrażonej tam normy prawnej strony mogą poddać zobowiązanie wybranemu przez siebie prawu w drodze porozumienia zawartego po wystąpieniu zdarzenia powodującego szkodę albo - w przypadku prowadzenia przez wszystkie strony działalności gospodarczej - również w drodze porozumienia swobodnie wynegocjowanego przed wystąpieniem takiego zdarzenia. Pomimo że rozporządzenie dopuszcza zarówno wybór uprzedni, jak i następczy, ze względu na przesłankę natury podmiotowej, warunkującą skuteczność wyboru dokonanego ex ante, praktyczne znaczenie zachowa tu jednak przede wszystkim porozumienie zawarte już po wystąpieniu zdarzenia stanowiącego źródło szkody ${ }^{38}$. Wybór prawa nie musi być dokonany w sposób wyraźny. Rozporządzenie dopuszcza także wybór dorozumiany, o ile w sposób dostatecznie pewny wynika on z okoliczności sprawy. Dokonany wybór prawa nie może jednak naruszać praw osób trzecich.

W świetle art. 14 ust. 2, jak i art. 24 rozporządzenia przedmiotem skutecznego wyboru może być jedynie prawo określonego państwa ${ }^{39}$.

36 P. Machnikowski, [w:] Prawo prywatne międzynarodowe. Komentarz, red. M. PAzDAN, Warszawa 2018, s. 908.

37 Por. S. Leible, M. Lehmann, op. cit., s. 728; G. Wagner, op. cit., s. 7; Ł. ŻarNOWIEc, Prawo właściwe dla odpowiedzialności za szkodę wyrzadzona przez produkt niebezpieczny w świetle przepisów rozporządzenia Rzym II, «PPPM» 5/2009, s. 102-103.

38 Ł. Żarnowiec, [w:] System..., s. 785.

39 Por. S. Leible, op. cit., s. 261. 
Zarazem jednak prawo to nie musi wykazywać obiektywnego związku z zobowiązaniem, a także nie musi należeć do państwa członkowskiego UE. Z zastrzeżeniem szczególnych przypadków uregulowanych w art. 14 ust. $2^{40}$ i $3^{41}$ przedmiotem wyboru może być zatem również prawo neutralne ${ }^{42}$.

Pomimo regulacji zawartej $\mathrm{w}$ art. 14 rozporządzenia, należy spodziewać się, że wybór prawa w omawianej tu kategorii spraw w praktyce będzie należał raczej do rzadkości. Zdecydowanie częściej do głosu dojdą natomiast normy kolizyjne posługujące się łącznikiem obiektywnym.

Pomimo licznych wątpliwości oraz dyskusji nad słusznością takiego rozwiązania, twórcy rozporządzenia zdecydowali się ostatecznie poświęcić problematyce odpowiedzialności za produkt odrębną normę kolizyjną wyrażoną $\mathrm{w}$ art. $5^{43}$. O jej przyjęciu przesądziło kilka argumentów. Pierwszym z nich było dążenie do zapewnienia równowagi między postulatem należytej ochrony poszkodowanych a usprawiedliwionym

40 Zgodnie $\mathrm{z}$ wyrażoną tam normą, jeżeli w chwili wystąpienia zdarzenia powodującego szkodę wszystkie elementy stanu faktycznego sprawy zlokalizowane są w państwie innym aniżeli to, którego prawo wybrano, dokonany przez strony wybór nie wyłącza zastosowania przepisów bezwzględnie wiążących wchodzących w skład systemu prawnego tego państwa. Dokonany wybór ma tutaj zatem jedynie skutki materialnoprawnego wskazania.

${ }^{41}$ Przepis ten reguluje skutki wyboru prawa państwa trzeciego (tj. niebędącego członkiem UE) wówczas, gdy wszystkie elementy stanu faktycznego są w chwili zdarzenia powodującego szkodę zlokalizowane w jednym lub kilku państwach członkowskich. Wybór taki nie wyłącza zastosowania bezwzględnie wiążących przepisów prawa wspólnotowego w kształcie, jaki uzyskały one na skutek ich implementacji do legem fori.

42 S. LeIBLE, op. cit., s. 261.

43 Tworzenie licznych wyjątków od ogólnej normy określającej prawo właściwe dla zobowiązań z czynów niedozwolonych poddano krytyce w literaturze - por. H. KozIoL, T. Thiede, Kritische Bemerkungen zum derzeitigen Stand des Entwurfs einer Rom II Verordnung, "Zeitschrift für vergleichende Rechtswissenschaft»106/2007, s. 235-247. Tak też, w odniesieniu do omawianej materii, na etapie prac nad projektem, Komisja ds. Unii Europejskiej Izby Lordów - por. The Rome II Regulation. Report with Evidence, London 2004, s. 34, nb 106. W kwestii historii prac nad omawianą normą prawną por. B. Heiderhoff, Eine europäische Kollisionsnorm für die Produkthaftung: Gedanken zur Rom II - Verordnung, «GPR» 2/2005, s. 92-97. 
interesem osób ponoszących ryzyko odpowiedzialności, wyrażającym się w zastosowaniu prawa, którego właściwość mogły racjonalnie przewidzieć $^{44}$. Drugi to eliminacja rozwiązań przypadkowych, zaskakujących nie tylko z perspektywy potencjalnie odpowiedzialnego przedsiębiorcy, ale i poszkodowanego ${ }^{45}$.

Zakres normy kolizyjnej z art. 5 rozporządzenia nie jest jednak wolny od wątpliwości, przy czym koncentrują się one na zagadnieniach kluczowych właśnie z punktu widzenia odpowiedzialności za szkodę wyrządzoną przez pojazd autonomiczny. Ich przyczyną jest brak w rozporządzeniu definicji legalnej produktu, pozwalającej na jednoznaczną identyfikację przypadków, do których norma ta znajduje zastosowanie. Stało się to przyczyną rozbieżności stanowisk prezentowanych w tej kwestii przez przedstawicieli doktryny. Zdaniem niektórych z nich ${ }^{46}$, na potrzeby przepisów rozporządzenia pojęciu temu należy nadawać sens wynikający z art. 2 dyrektywy Rady 85/374/EWG. Przy takim założeniu produktem byłyby jedynie rzeczy ruchome, nawet jeśli zostały połączone z inną rzeczą (czy to ruchomą, czy to nieruchomą), z uwzględnieniem energii elektrycznej. Prowadziłoby to do wyłączenia poza zakres pojęcia „produkt”, a w konsekwencji także i normy z art. 5 między innymi produktów stanowiących dobra niematerialne, w tym - co kluczowe, gdy chodzi o specyfikę pojazdów autonomicznych - treści cyfrowych ${ }^{47}$. W kontekście celów rozporządzenia, a także wskazań wynikających z motywu 11 jego preambuły bardziej uzasadnione wydaje się jednak

44 Por. Hamburg Group for Private International Law, Comments on the European Commission's Draft Proposal for a Council Regulation on the Law Applicable to Non-Contractual Obligations, s. 15. W kwestii znaczenia kryterium przewidywalności - por. T. PAJOR, op. cit., s. 9.

45 Ł. Żarnowiec, [w:] System..., s. 776.

46 Por. P. Stone, The Rome II Regulation On Choice Of Law In Tort, "Ankara Law Review» 2/2007, s. 118; IDEM, Product Liability under the Rome II Regulation, [w:] The Rome II 2009, red. J. Ahern, W. Binchy, s. 181; P. Huber, M. Illmer, International Product Liability. A Commentary on Article 5 of The Rome II Regulation, YPIL 9/2007, s. 37-38; J. Von HEIN, Europäisches Internationales Deliktsrecht nach der Rom II - Verordnung, «Zeitschrift für Europäisches Privatrecht»1/2009, s. 26.

47 P. Machnikowski, op. cit., s. 909. 
nadawanie pojęciu produktu znaczenia autonomicznego ${ }^{48}$. Pozwoliłoby to uniknąć jego ograniczenia - w płaszczyźnie kolizyjnoprawnej - do jakiejkolwiek z góry założonej kategorii przedmiotów, a w konsekwencji objąć nim wszelkiego rodzaju dobra materialne i niematerialne, ruchome i nieruchome, $\mathrm{w}$ stanie przetworzonym lub naturalnym, mogące stanowić przedmiot obrotu ${ }^{49}$, nie wyłączając treści cyfrowych czy baz danych $^{50}$.

Nie wydaje się również słuszne ograniczanie zakresu normy kolizyjnej z art. 5 rozporządzenia wyłącznie do odpowiedzialności za szkodę wyrządzoną przez produkt wadliwy ${ }^{51}$. Trzeba pamiętać, że jedną $\mathrm{z}$ istotniejszych zmian wprowadzonych do omawianego przepisu $\mathrm{w}$ toku procedury legislacyjnej była rezygnacja $\mathrm{z}$ proponowanego pierwotnie, zawężającego sformułowania defective product ${ }^{52}$. Zatem przepis w swym ostatecznym brzmieniu odnosi się do szkody wyrządzonej przez produkt nie tyle wadliwy, ile niebezpieczny, przy czym owo niebezpieczeństwo może stanowić naturalną cechę danej kategorii produktu, niekoniecznie zaś wynikać z tkwiącej w nim wady ${ }^{53}$.

W nakreślonym powyżej, szerokim zakresie normy kolizyjnej z art. 5 rozporządzenia z pewnością mieści się szkoda będąca konsekwencją udziału w ruchu pojazdów autonomicznych. Pozostaje zatem przejść do wskazania kryteriów, z wykorzystaniem których odbywa się wyznaczenie prawa właściwego. I tak, jako pierwsze znajdzie zastosowanie prawo państwa, w którym w chwili powstania szkody obie strony mają miejsce zwykłego pobytu (art. 5 ust. 1 w zw. $z$ art. 4 ust. 2 rozporządzenia

48 Tak jeszcze w okresie prac nad projektem - M. JAGIELSKA, Prawo właściwe dla odpowiedzialności za produkt - rozważania na tle projektu rozporządzenia WE o prawie właściwym dla zobowiazań pozaumownych, [w:] Rozprawy prawnicze. Księga pamiatkowa Profesora Maksymiliana Pazdana, red. L. Ogiegło, W. Popiołek, M. Szpunar, Kraków 2005, s. 119.

49 R. Plender, M. Wilderspin, The European Private International Law, Oxford 2009, s. 551.

50 Ibidem, s. 551; Ł. Żarnowiec, op. cit., s. 779; P. MaChnikowski, op. cit., s. 909.

51 Por. M. Illmer, The New European Private International Law of Product Liability - Steering Through Troubled Waters, «RabelsZ» 73/2009, s. 281-282.

52 A. Dickinson, op. cit., s. 370.

53 P. Machnikowski, op. cit., s. 910. 
Rzym II). Jeżeli brak jest tej przesłanki, prawem właściwym dla zobowiązania pozaumownego z tytułu szkody wyrządzonej przez produkt jest:

1. prawo państwa, w którym poszkodowany ma, $\mathrm{w}$ chwili powstania szkody, miejsce zwykłego pobytu, jeżeli produkt został wprowadzony do obrotu w tym państwie, lub w braku takiego prawa;

2. prawo państwa, $\mathrm{w}$ którym produkt nabyto, jeżeli został on wprowadzony do obrotu w tym państwie, lub w przypadku gdy nie zachodzi ta okoliczność;

3. prawo państwa, w którym powstała szkoda, jeżeli produkt został wprowadzony do obrotu w tym państwie.

Prawem właściwym jest jednak prawo państwa miejsca zwykłego pobytu osoby, której przypisuje się odpowiedzialność, jeżeli osoba ta nie mogła w uzasadniony sposób przewidzieć wprowadzenia produktu lub produktu tego samego rodzaju do obrotu w państwie, którego prawo stosuje się zgodnie z pkt 1-3.

Wyrażona w art. 5 norma kolizyjna uwzględnia z jednej strony postulat ochrony uzasadnionych oczekiwań poszkodowanego, z drugiej zaś zabezpiecza interesy podmiotu pociągniętego do odpowiedzialności ${ }^{54}$. Prawem dochodzącym do głosu w pierwszej kolejności zgodnie z kaskadą łączników jest prawo miejsca zwykłego pobytu poszkodowanego z chwili wystąpienia szkody. Chodzi tutaj o system prawny państwa, w którym koncentrują się jego interesy życiowe, a więc z którym poszkodowany (z reguły konsument) jest najlepiej zaznajomiony. Zarazem jednak w przypadku każdego z rozwiązań wskazanych w art. 5 ust. 1 zd. 1 lit. a-c, interes podmiotu mogącego potencjalnie ponieść odpowiedzialność doznaje należytej ochrony. Z właściwością prawa państwa zwykłego pobytu poszkodowanego, prawa państwa nabycia produktu względnie prawa miejsca wystąpienia szkody musi on liczyć się jedynie o tyle, o ile produkt na terenie danego państwa wprowadzono do obrotu, a on sam - rozsądnie rzecz biorąc - mógł to przewidzieć. W takim wypadku można zasadnie od niego oczekiwać dostosowania produktu do obowiązujących tam standardów bezpieczeństwa, zapoznania się

54 Por. M. Hibbert, New EU choice of law rules for tort and product liability claims finalised, «European Product Liability Review» 9/2007, s. 12-14. 
z obowiązującymi zasadami odpowiedzialności za produkt, a wreszcie skalkulowania ceny tak, by pokrywała ona ryzyko jej poniesienia ${ }^{55}$. Gdy przesłanki te nie zostaną spełnione w odniesieniu do żadnego z państw, o których mowa w art. 5 ust. 1 zd. 1 rozporządzenia, jego odpowiedzialność będzie kształtowała się według prawa państwa miejsca jego zwykłego pobytu ${ }^{56}$.

Zastosowanie może ponadto znaleźć reguła korekcyjna, bazująca na kryterium znacznie ściślejszego związku (art. 5 ust. 2). W praktyce sięgnięcie po nią będzie uzasadnione zwłaszcza w relacjach między podmiotem pociągniętym do odpowiedzialności a pierwszym nabywcą produktu - występującymi równocześnie w charakterze stron umowy. Należy jednak unikać wszelkiego automatyzmu w jej stosowaniu, każdorazowo opierając się na wnikliwej ocenie okoliczności konkretnego przypadku' ${ }^{57}$.

\section{OgólNy MODEL KOLIZYJNOPRAWNY ROZPORZĄDZENIA RZYM II}

W celu pełnego osiągnięcia rozwiązań kolizyjnoprawnych warto przedstawić w skrócie ogólny model przyjęty w rozporządzeniu Rzym II.

Normy kolizyjne dotyczące odpowiedzialności deliktowej zamieszczone w rozporządzeniu Rzym II obejmują zarówno odpowiedzialność opartą na zasadzie winy, jak i na zasadzie ryzyka. Zakres zastosowania statutu deliktowego obejmuje również zdolność deliktową.

Prawo wskazane przez rozporządzenie stosuje się bez względu na to, czy jest ono prawem państwa członkowskiego (art. 3). Normy kolizyjne mają więc charakter uniwersalny.

Podstawowa norma kolizyjna zawarta w art. 4 ust. 1 rozporządzenia posługuje się łącznikiem miejsca powstania szkody (właściwość legis loci damni). Zgodnie z nią prawem właściwym dla zobowiązania pozaumownego wynikającego z czynu niedozwolonego jest prawo państwa,

55 Por. G. WAgner, op. cit., s. 382.

56 Por. specyficzne ujęcie miejsca zwykłego pobytu podmiotów prowadzących działalność gospodarczą w art. 23 rozporządzenia.

57 Ł. Żarnowiec, [w:] System..., s. 784. 
w którym powstaje szkoda, niezależnie od tego, w jakim państwie miało miejsce zdarzenie powodujące szkodę oraz niezależnie od tego, w jakim państwie lub państwach występują skutki pośrednie tego zdarzenia; w przepisie tym chodzi o miejsce, gdzie nastąpiła szkoda bezpośrednia; miejsce szkód pośrednich nie ma żadnego znaczenia.

Przewidziano odstępstwo od tej zasady na rzecz łącznika personalnego. Jeżeli osoba, której przypisuje się odpowiedzialność, oraz poszkodowany mają w chwili powstania szkody miejsce zwykłego pobytu (chodzi o miejsce zwykłego pobytu w tym samym państwie), stosuje się to prawo zgodnie $\mathrm{z}$ ust. 2 art. 4.

Istotne znaczenie w przypadku szkód wyrządzonych przez pojazdy autonomiczne może mieć reguła korekcyjna, wedle której, jeżeli ze wszystkich okoliczności sprawy wyraźnie wynika, że czyn niedozwolony pozostaje w znacznie ściślejszym związku z innym państwem niż państwo wskazane w art. 4 ust. 1 i 2, należy stosować prawo tego innego państwa.

Wreszcie warto przypomnieć, o czym piszemy w poprzednim punkcie, że rozporządzenie Rzym II dopuszcza dla zobowiązań pozaumownych wybór prawa (art. 14), nie tylko gdy chodzi o odpowiedzialność za produkt niebezpieczny. Następczy wybór prawa nie wymaga spełnienia warunków. Z kolei wyboru uprzedniego mogą dokonać podmioty prowadzące działalność gospodarczą również w porozumieniu swobodnie wynegocjowanym przed wystąpieniem zdarzenia powodującego szkodę.

\section{Problemy WidoczNe w ORZECZNiCtwie SĄDOWYM}

Polskie sądy orzekające o odpowiedzialności za szkody wyrządzone w związku z wypadkiem drogowym o charakterze międzynarodowym mają już teraz spore trudności ze stwierdzeniem, czy zastosować należy reżim rozporządzenia Rzym II czy konwencji haskiej z 1971 r. Jako przykład wskazać można wyrok Sądu Apelacyjnego w Szczecinie z 7 lutego 
2014 r., I ACa 660/1258. Powodami byli obywatele polscy mający miejsce zamieszkania w Polsce. Do wypadku drogowego doszło w Niemczech. Sprawcą wypadku był obywatel polski. Sąd pierwszej instancji trafnie stwierdził, że rozporządzenie Rzym II nie stosuje się, ponieważ znajduje ono zastosowanie dopiero do zdarzeń powodujących szkodę, które miały miejsce po wejściu w życie rozporządzenia. Prawidłowo uznał też, że prawo właściwe ustalić należy na podstawie konwencji haskiej z 1971 r., której stroną jest Polska. Na podstawie art. 3 konwencji sąd zastosował prawo niemieckie jako prawo państwa, w którym nastąpił wypadek. Zwrócił uwagę, że konwencja ma zastosowanie uniwersalne (art. 11 konwencji). Nie stanowiło przeszkody dla jej stosowania to, że wypadek miał miejsce na terenie Niemiec, które to państwo nie jest członkiem konwencji haskiej. Niestety Sąd Apelacyjny uchylił wyrok sądu I instancji. Nietrafnie przyjął właściwość korzystniejszego dla powodów pod względem charakteru przysługujących im roszczeń prawa polskiego. Nie bacząc na fakt, że konwencja haska z 1971 r. wyłącza odesłanie, błędnie odwołał się do art. 40 niemieckich przepisów kolizyjnoprawnych (EGBGB), zgodnie z którym jeżeli w momencie, w którym nastąpiło zdarzenie powodujące szkodę, sprawca i poszkodowany mają zwykłe miejsce pobytu w tym samym państwie, stosuje się prawo tego państwa. W sprawie zarówno poszkodowani, jak i sprawca byli obywatelami polskimi i, jak się wydaje na podstawie wywodów sądu, mieli tam miejsce zamieszkania. Paradoksem jest, że przyjęte w przywołanym wyroku - błędne, choć równocześnie korzystne z perspektywy poszkodowanych powodów - rozwiązanie kolizyjnoprawne odpowiada temu, w jaki sposób prawo właściwe w tym samym stanie faktycznym ustalałby sąd orzekający w Niemczech. Pozwala to uzmysłowić sobie, jak realnym niebezpieczeństwem jest w omawianej kategorii spraw zjawisko

58 Pełne, krytyczne omówienie przedstawionych orzeczeń zawiera opracowanie: J. Pazdan, M.-A. Zachariasiewicz, M. Pazdan, M. Świerczyński, M. ZachariaSIEWICZ, W. KUROWSKI, K. PACUŁA, Uwagi o uregulowaniach rozporządzenia Rzym II i ich stosowaniu na tle doświadczeń polskiej judykatury, «Problemy Prawa Prywatnego Międzynarodowego» 16/2015, s. 81 i n. W niniejszym artykule zwracamy uwagę tylko na wybrane aspekty, istotne dla szkód wyrządzonych przez pojazdy autonomiczne. 
forum shopping ${ }^{59}$, któremu w odniesieniu do materii zobowiązań pozaumownych czy opartej na konstrukcji actio directa odpowiedzialności ubezpieczyciela za skutki kwalifikowanych w ten sposób szkód sprzyja kształt norm jurysdykcyjnych ${ }^{60}$ wprowadzonych przepisami rozporządzenia Parlamentu Europejskiego i Rady (UE) nr 1215/2012 z 12 grudnia 2012 r. w sprawie jurysdykcji i uznawania orzeczeń sądowych oraz ich wykonywania w sprawach cywilnych i handlowych (Bruksela I bis) ${ }^{61}$.

\section{ProponoWANE ROZWIĄZANIA}

Na wskazane we wstępie opracowania pytania badawcze należy odpowiedzieć następująco. Obowiązujące w poszczególnych państwach członkowskich UE normy kolizyjne pozwalają wyznaczyć prawo właściwe do oceny odpowiedzialności za szkodę wyrządzoną wskutek wypadku drogowego spowodowanego przez autonomiczny pojazd. Pomimo zakończonej co do zasady sukcesem unifikacji w obszarze międzynarodowego prawa zobowiązań pozaumownych, różnią się one jednak nadal w zależności od miejsca jurysdykcji, a niezależnie od tego są nazbyt złożone i skomplikowane. W konsekwencji ich aktualny kształt rodzi ryzyko zjawiska forum shopping, a dodatkowo utrudnia sytuację prawną poszkodowanemu w dochodzeniu swoich roszczeń. Uważamy za zasadne wprowadzenie w nich zmian w celu ujednolicenia i uproszczenia modelu kolizyjnoprawnego. Poniżej przedstawiamy rekomendowane rozwiązania.

Optymalnym rozwiązaniem jest stworzenie jednolitej merytorycznoprawnej (materialnoprawnej) regulacji odpowiedzialności za szkody

59 W kwestii praktycznego wymiaru wynikających stąd problemów na tle przykładowych stanów faktycznych - T. Graziano, Das auf außervertragliche..., s. 27-29; C. Nagy, The Rome II..., s. 104-106.

60 C. NAgy, The Rome II..., s. 94; C. BRière, Le règlement (CE) $n^{\circ}$ 864/2007 du 11 juillet 2007 sur la loi applicable aux obligations non contractuelles (Rome II), «Revue trimestrielle LexisNexis JurisClasseur» 1-3/2008, s. 72; B. VERSCHR AEGEN, Internationales Privatrecht, Wien 2012, s. 152.

61 Dz. Urz. UE 2012 L 351/1. 
wyrządzone $\mathrm{z}$ udziałem pojazdów autonomicznych ${ }^{62}$. Oznaczałoby to przyjęcie przez UE stosownej regulacji, na przykład w formie rozporządzenia unijnego. Ujednolicenie powinno dotyczyć przede wszystkim odpowiedzialności odszkodowawczej ${ }^{63}$ oraz zasad przedawnienia roszczeń (ze względu na różne terminy przedawnienia roszczeń w poszczególnych państwach członkowskich) ${ }^{64}$. Trudno jednak oczekiwać, aby nastąpiło to w najbliższym czasie.

W drugiej kolejności należy więc rozważyć zmianę przepisów kolizyjnoprawnych.

Jednym z możliwych rozwiązań jest wprowadzenie do rozporządzenia Rzym II przepisów dotyczących wypadków drogowych. Taki odrębny przepis zaproponowano już w projekcie rozporządzenia z 2005 r. Przepisy te mogłyby odzwierciedlać regulację konwencji haskiej z 1971 r. Oznaczałoby to asymilację konwencji w rozporządzeniu, co skutkowałoby ujednoliceniem metod wyznaczania prawa właściwego we wszystkich państwach członkowskich UE, uczestniczących w rozporządzeniu, bez względu na ich przynależność do kręgu państw - stron konwencji haskiej bądź jej brak. Rozwiązanie takie realizowałoby jeden z głównych celów rozważanych zmian, eliminując ryzyko zjawiska forum shopping. Zarazem jednak, z uwagi na skomplikowany system doboru i kombinacji kryteriów podniesionych do rangi łączników, przenosiłoby na płaszczyznę rozporządzenia trudności w ustaleniu prawa właściwego znane $\mathrm{z}$ konwencji haskiej. Takie rozwiązanie nie wydaje się zatem ani konieczne, ani zasadne ${ }^{65}$.

62 Tak np. N. Nevejans, op. cit., s. 704.

63 W kwestii różnic między rozwiązaniami występującymi w poszczególnych systemach prawnych por. T. Graziano, C. Oertel, Ein europäisches Haftungs- und Schadensrecht für Unfälle im Straßenverkehr? - Eckpunkte de lege lata und Überlegeungen de lege ferenda, «ZVglRWiss» 107/2008, s. 113-163.

64 Por. A. Dickinson, op. cit., s. 362; T. Graziano, Report 2016, oraz H. JacqueMin, J.-B. Hubin, Aspects contractuels..., s. 112-120.

65 Tak M. Pazdan, M. Jagielska, W. Kurowski, M. Świerczyński, A.-M. ZACHARIASIEWICZ, M. ZACHARIASIEWICZ, Ł. ŻARNOWIEC, W odpowiedzi na ankiete skierowana do państw członkowskich Unii, dotycząca stosowania Rozporządzenia nr 864/2007 o prawie właściwym dla zobowiązań pozaumownych (Rzym II), «Problemy Prawa Prywatnego Międzynarodowego»12/2013, s. 171. 
Problematyka wypadków drogowych przy udziale autonomicznych pojazdów nie uzasadnia naszym zdaniem zasadniczej zmiany sposobu ustalania prawa właściwego w kierunku uprzywilejowania poszkodowanego ${ }^{66}$. Przykładem takiego rozwiązania byłoby rozbicie statutu deliktowego w taki sposób, aby kwestie rodzaju pokrywanych szkód oraz sposobu liczenia odszkodowania podlegały prawu państwa, w którym znajduje się miejsce zwykłego pobytu poszkodowanego ${ }^{67}$. Nie wydaje się to zasadne ${ }^{68}$. Nie uzasadnia tego specyfika szkód wyrządzonych z udziałem pojazdów autonomicznych. Nie można wymagać od sprawcy szkody, aby musiał się liczyć z potencjalną właściwością w tym względzie różnych praw, zwłaszcza gdy w danym stanie faktycznym często nie miałby wręcz możliwości zorientowania się z góry co do okoliczności przesądzających o ich zastosowaniu ${ }^{69}$. W przypadku pojazdów autonomicznych argument ten dodatkowo zyskuje na znaczeniu, skoro sprawcą szkody niekoniecznie musi być posiadacz pojazdu. Uzasadnione jest więc pozostanie przy zasadniczej właściwości prawa miejsca bezpośredniej szkody (miejsca wypadku). Rozwiązanie to stanowi kompromis zarówno dla sprawcy (który nie może polegać na swoim prawie), jak i dla poszkodowanego, który nie może powoływać się (tak jak konsument czy pracownik) na korzystniejsze regulacje prawne, pochodzące z prawa państwa jego miejsca zwykłego pobytu ${ }^{70}$. Nie byłoby natomiast wykluczone sięgnięcie w takim wypadku do określonych norm mery-

66 Analogicznie do przypadku uprzywilejowania strony słabszej, np. konsumentów w prawie prywatnym międzynarodowym - por. H. JACQUEMIN, J.-B. Hubin, Aspects contractuels..., s. 89-93.

67 Rozwiązanie takie zaproponowane zostało podczas pierwszego czytania projektu rozporządzenia Rzym II w Parlamencie, jednak z uwagi na sprzeciw Komisji i Rady nie znalazło się w ostatecznie przyjętym tekście - por. S. Symonides, Rome II and Tort Conflicts: A Missed Opportunity, «AmJCL» 2008, s. 205; J. Von HeIn, Article 4..., s. 155 i 160 .

68 Krytycznie w kwestii takiego rozwiązania: H. Unberath, J. CzIUPKA, [w:] Europäisches Zivilprozess- und Kollisionsrecht EuZPR/EuIPR Kommentar, red. T. RAUsCHER, München 2011, s. 741.

${ }^{69}$ M. Pazdan, M. Jagielska, W. Kurowski, M. Świerczyński, A.-M. ZachaRIASIEWICZ, M. ZACHARIASIEWICZ, Ł. ŻARnOWIEC, op. cit., s. 171.

70 Ibidem, s. 171. 
torycznych przepisów wymuszających swoje zastosowanie (gdy stosowna regulacja materialnoprawna zostanie już przyjęta), na przykład wynikających z prawa, w którym znajduje się miejsce zwykłego pobytu poszkodowanego. Do chwili przyjęcia przepisów krajowych o pojazdach autonomicznych sytuacja ta wydaje się jednak wyjątkowa, chociaż nie można wykluczyć jej wystąpienia na tle art. 16 rozporządzenia Rzym II ${ }^{71}$.

Powstaje pytanie, jak przedstawionemu powyżej rozwiązaniu modelowemu zapewnić moc obowiązującą. Naszym zdaniem zasadne jest wykorzystanie jako punktu wyjścia ogólnych przepisów rozporządzenia Rzym II, w szczególności jego art. 4. Nie powinno ulegać wątpliwości, że konwencja haska z 1971 r. jest aktem gorszym jakościowo od rozporządzenia Rzym II ${ }^{72}$. Jest nadmiernie kazuistyczna. W nieuzasadniony sposób przyznaje znaczenie miejscu rejestracji (a wyjątkowo także stałego stacjonowania) pojazdu, które stanowi substytut miejsca zwykłego pobytu kierowcy, właściciela lub posiadacza pojazdu, chroniąc w ten sposób interesy ich oraz ich ubezpieczyciela. Nie znajduje uzasadnienia poddanie rodzaju szkód i ich oceny prawu osoby, której przypisuje się odpowiedzialność. Przemawia to za przyznaniem we wszystkich państwach członkowskich pierwszeństwa postanowieniom rozporządzenia Rzym II w stosunku do przepisów konwencji, przynajmniej w przypadku tych stanów faktycznych, w których zarówno poszkodowany, jak i podmiot pociągnięty do odpowiedzialności posiadali w chwili wypadku miejsce zwykłego pobytu w państwie członkowskim $\mathrm{UE}^{73}$.

W przypadku obu aktów prawnych podstawowa reguła jest analogiczna i w tym zakresie metoda ustalania prawa właściwego nie uległaby

71 Co do znaczenia tego przepisu por. zwłaszcza: Ł. Żarnowiec, Przepisy wymuszajace swoje zastosowanie $w$ świetle rozporządzenia Parlamentu Europejskiego i Rady (WE) nr 864/2007 z dnia 11 lipca 2007 r., o prawie właściwym dla zobowiazań pozaumownych - „Rzym II” (Dz. Urz. UE 2007 L 199/40), [w:] Państwo i prawo w dobie globalizacji. Księga jubileuszowa, Rzeszów 2011, s. 340-355; IdEM, [w:] System..., s. $862-869$.

72 Por. A. Staudinger, P. Czaplinski, Verkehrsopferschutz im Lichte der Rom I-, Rom II- sowie Brüssel I-Verordnung, «NJW» 3/2009, s. 2254.

73 Tak T. Graziano, Das aufaußervertragliche..., s. 31; M. Pazdan, M. Jagielska, W. Kurowski, M. Świerczyński, A.-M. ZaChariasiewicz, M. ZaChariasiewiCZ, Ł. ŻARNOWIEC, op. cit., s. 171. 
zmianie. Zgodnie z konwencją haską z 1971 r. (art. 3) zastosowanie znajduje prawo miejsca wypadku, a według rozporządzenia Rzym II prawo miejsca bezpośredniej szkody (art. 4 ust. 1) ${ }^{74}$. W przypadku obu aktów prawnych za dopuszczalny uznaje się również następczy wybór prawa ${ }^{75}$. Co godne przypomnienia, normy kolizyjne rozporządzenia Rzym II są natomiast już obecnie miarodajne w sprawach, które konwencja haska z 1971 r. wyłącza poza swój przedmiotowy zakres. Zasadnicza różnica dotyczy natomiast sytuacji, gdy poszkodowany, jak i osoby, którym przypisuje się odpowiedzialność, mają miejsce zwykłego pobytu w tym samym państwie. W tym przypadku rozporządzenie Rzym II prowadzi do zastosowania prawa państwa miejsca zwykłego pobytu stron sporu (art. 4 ust. 2) ${ }^{76}$. Jest to jednak znacząca zaleta rozporządzenia Rzym II w porównaniu z konwencją z 1971 r. ${ }^{77}$ Ponadto rozporządzenie Rzym II pozwala na wykorzystanie w stosownych przypadkach reguły korekcyjnej (art. 4 ust. 3), równocześnie nie przypisując żadnego znaczenia słusznie krytykowanemu na tle konwencji z 1971 r. kryterium miejsca rejestracji pojazdu ${ }^{78}$. Rekomendowanym rozwiązaniem jest więc przyznanie pierwszeństwa rozporządzeniu Rzym II przed konwencją haską z 1971 r., co wymagałoby jednak wprowadzenia odpowiedniej korekty do treści art. $28^{79}$. Żałować można, że dotychczas nie wykorzystano w tym celu sposobności, jaką stwarzała klauzula przeglądowa $\mathrm{z}$ art. 30 rozporządzenia ${ }^{80}$.

74 Co do praktycznej zbieżności wskazań wynikających z zastosowania obu łączników por. C. NAGY, op. cit., s. 98-99, 102.

75 O korzyściach z tym związanych por. szerzej A. Mills, Party Autonomy in Private International Law, Oxford 2018, s. 390-454.

76 Co do praktycznego znaczenia tej normy w odniesieniu do wypadków drogowych por. A. Junker, Das internationale Privatrecht der Straßenverkehrsunfälle nach der Rom II - Verordnung, «JZ» 4/2008, s. 174.

77 Tak trafnie T. Graziano, Das auf außervertragliche..., s. 27; T. Graziano, Report 2016, s. 55; C. NAGY, op. cit., s. 107.

78 C. Nagy, op. cit., s. 107.

79 A. Halfmeier, N. Sonder, op. cit., s. 642-643; C. Nagy, op. cit., s. 108.

80 Nadzieje takie wyrażano w doktrynie; por. A. Dickinson, op. cit., s. 362; A. Staudinger, P. Czaplinski, op. cit., s. 2254. 
Inaczej przedstawia się natomiast sprawa, gdy chodzi o potencjalną odpowiedzialność producentów (importerów lub sprzedawców) pojazdów autonomicznych, ich części czy też treści cyfrowych, w oparciu o które pojazdy te funkcjonują. W tym wypadku dodatkowym argumentem, który należy mieć na uwadze, jest ogólnospołeczny interes we wspieraniu rozwoju technologicznego oraz związany z nim postulat sprawiedliwego podziału ryzyk, towarzyszących wdrażaniu innowacyjnych rozwiązań. Czynniki te przemawiają za tym, by w granicach, w jakich nie narusza to uzasadnionego interesu poszkodowanego, potencjalnie zagrożonemu odpowiedzialnością przedsiębiorcy zapewnić minimalny poziom ochrony, wyrażający się gwarancją zastosowania prawa należącego do jednego z państw, w którym pojazd (jego część bądź wykorzystany w nich algorytm) zostały wprowadzone do obrotu, co on sam - rozsądnie rzecz biorąc - mógł i powinien przewidzieć. Realizacji tych założeń służy kolizyjnoprawna regulacja odpowiedzialności za produkt przyjęta w art. 5 rozporządzenia Rzym II. Choć na jej tle powstają wątpliwości interpretacyjne, których definitywne rozstrzygnięcie leży w gestii TSUE, ciężar argumentów przywoływanych w doktrynie przemawia za umieszczeniem w zakresie wyrażonej tam normy kolizyjnej nie tylko odpowiedzialności za pojazd autonomiczny, ale i za użyte do jego budowy części elektroniczne czy wykorzystane w nich treści cyfrowe. Mimo że wyznaczenie prawa właściwego jest w tym wypadku procesem bez wątpienia bardziej złożonym niż w przypadku ogólnie miarodajnej dla deliktów normy z art. 4, wskazane powyżej racje przemawiają za odejściem od kolizyjnoprawnej prostoty na rzecz odpowiedniego wyważenia interesów i ryzyk innowacyjnego przedsiębiorcy oraz pozostałych uczestników obrotu, w tym podmiotów potencjalnie narażonych na szkodę. Za takim rozwiązaniem przemawia jeszcze jeden ważki argument. Otóż przedstawiona metoda postępowania jest zbieżna $\mathrm{z}$ tą, jaka znalazłaby zastosowanie $\mathrm{w}$ odniesieniu do odpowiedzialności producenta (importera, sprzedawcy) każdego innego pojazdu. Trudno natomiast znaleźć racjonalne argumenty, które przemawiałyby za szczególnym (mniej korzystnym) podejściem do wytwórców pojazdów autonomicznych, zwłaszcza jeżeli wziąć pod uwagę powszechność wykorzystania treści cyfrowych we współczesnej 
motoryzacji. Nawet jeśli nie służą one wspieraniu lub korygowaniu umiejętności kierowcy, odpowiadając za działanie systemów mechanicznych pozostających niejako $\mathrm{z}$ natury rzeczy poza jego kontrolą, trudno uznać, by ryzyko szkód wynikających $\mathrm{z}$ ich zastosowania było w takim wypadku mniejsze. Za przykład może posłużyć nagłe zatrzymanie funkcji pojazdu w ruchu wskutek awarii mikroprocesorowego sterownika wtrysku albo zapłonu silnika, nagła utrata sprawności elektronicznie sterowanego układu hamulcowego, nagła awaria zespołu sterowania zapalnikami poduszek powietrznych czy elektronicznego naprężacza pasów bezpieczeństwa.

Aprobując rozwiązanie przyjęte $\mathrm{w}$ art. 5 rozporządzenia Rzym II, należy jednak przypomnieć, że podstawowym zarzutem formułowanym wobec obowiązującego w UE modelu wyznaczania prawa właściwego do oceny odpowiedzialności za produkt jest - podobnie jak w przypadku odpowiedzialności za wypadki drogowe - dualizm źródeł prawa, wynikający tutaj z obowiązywania w części państw członkowskich konwencji haskiej z 1973 r. ${ }^{81}$ Przedstawiona powyżej krytyczna ocena zawartych w konwencji rozwiązań także i w tym wypadku sprzeciwia się ewentualnym próbom ich przejęcia do treści rozporządzenia. Dążenie do uniknięcia zjawiska forum shopping nie jest dostatecznym uzasadnieniem dla zastąpienia regulacji jakościowo lepszej gorszą. Podobnie jak w przypadku konwencji haskiej z 1971 r. zdecydowanie korzystniejszą i prostszą opcją wydaje się przyznanie pierwszeństwa przed konwencją rozporządzeniu Rzym II, co jednak wymagałoby odpowiedniej ingerencji w treść art. 28.

${ }^{81}$ Tak M. Pazdan, M. Jagielska, W. Kurowski, M. Świerczyński, A.-M. ZACHARIASIEWICZ, M. ZaCHARIASIEWICZ, Ł. ŻARnOWIEC, op. cit., s. 177-178. 


\section{PRAWO WŁAŚCIWE DLA ODPOWIEDZIALNOŚCI ZA SZKODĘ SPOWODOWANĄ PRZEZ WYPADKI DROGOWE Z UDZIAEEM AUTONOMICZNYCH POJAZDÓW}

\section{Streszczenie}

Niniejszy artykuł dotyczy odpowiedzialności za szkodę spowodowaną przez wypadki drogowe $\mathrm{z}$ udziałem autonomicznych pojazdów. Przedmiotem analizy i krytyki jest regulacja kolizyjnoprawna przyjęta w rozporządzeniu Rzym II oraz obu konwencjach haskich z 1971 i 1973 r. Badane aspekty obejmują klasyfikację szkód i odpowiedzialnych podmiotów. Po zbadaniu tych aktów prawnych staje się jasne, że istniejący model kolizyjno prawny jest bardzo złożony i skomplikowany. W rezultacie autorzy przedstawiają możliwe zmiany w przepisach kolizyjnych, mając na uwadze potrzebę ochrony osoby poszkodowanej. Pozwoli to na bardziej indywidualne rozpatrzenie danego przypadku i może doprowadzić do lepszego rozstrzygnięcia sporów. Wyniki mogą być przydatne dla oceny algorytmów sztucznej inteligencji w prawie prywatnym międzynarodowym.

The Law Applicable to Liability for Damage Caused by Road Accidents Involving Autonomous Vehicles

\section{Summary}

This paper elaborates on the law applicable to liability for damage caused by road accidents involving autonomous vehicles. We analyse and criticise the existing conflict-of-law framework adopted in the Rome II Regulation and both Hague Conventions of 1971 and 1973. The aspects we examine include classification of damage and liable entities. The examination of these legal acts shows that the existing model is very complex and complicated. We present potential changes to the conflict-of-law regulation, having in mind the need to protect the injured person. These changes would allow for a more individual consideration of specific cases and may lead to a more satisfactory outcome of ensuing disputes. 
Our findings may be useful in the assessment of artificial intelligence algorithms in private international law.

Słowa kluczowe: pojazdy autonomiczne; wypadki drogowe; normy kolizyjne; algorytmy sztucznej inteligencji.

Keywords: autonomous vehicles; road accidents; conflict-of-law rules; artificial intelligence algorithms.

\section{Literatura}

Akerkar R., Introduction to Artificial Intelligence, [w:] Artificial Intelligence for Business, red. R. AKerkar, Cham 2019, s. 1-18.

BRIÈRE C., Le règlement (CE) nº 864/2007 du 11 juillet 2007 sur la loi applicable aux obligations non contractuelles (Rome II), «Revue trimestrielle LexisNexis JurisClasseur» 1-3/2008, s. 31-74.

Calliess G. (red.), Rome Regulations: Commentary on the European Rules of the Conflict of Laws, Alphen aan den Rijn 2011.

Cassart A., Aéronefs sans pilote, voitures sans conducteur: la destination plus importante que le voyage, [w:] L'intelligence artificielle et le droit, red. H. Jacquemin, A. De Streel, Bruxelles 2017.

Civil Law Rules on Robotics. European Parliament resolution of 16 February 2017 with recommendations to the Commission on Civil Law Rules on Robotics (2015/2103(INL), P8_TA(2017)0051.

Di Meglio C., Coslin C., EC Regulation on law applicable to non-contractual obligations: Will Rome II ever be applicable to product liability claims in France?, «European Product Liability Review» 12/2007, s. 568-574.

Dickinson A., The Rome II Regulation: The law applicable to non-contractual obligations, Oxford 2008.

GARRIGA G., Relationships between "Rome II" and Other International Instruments. A Commentary on Article 28 of The Rome II Regulation, "YPIL» 9/2007, s. 137-143.

Graziano T., Cross-border Traffic Accidents in the EU - the Potential Impact of Driverless Cars, European Parliament - Directorate-General for Internal Policies of the Union, Brussels 2016.

Graziano T., Das auf außervertragliche Schuldverhältnisse anzuwendende Recht nach Inkrafttreten der Rom II - Verordnung, «RabelsZ»73/2009, s. 1-77.

GrazIANo T., Le nouveau droit international privé communautaire en matière de responsabilitè extracontractuelle, «RCDIP» 8-9/2008, s. 445-511. 
Graziano T., Oertel C., Ein europäisches Haftungs- und Schadensrecht für Unfälle im Straßenverkehr? - Eckpunkte de lege lata und Überlegeungen de lege ferenda, «ZVglRWiss» 107/2008, s. 439-487.

Gurney J., Sue my car not me: Products liability and accidents involving autonomous vehicles, "University of Illinois Journal of Law, Technology and Policy» 2/2013, s. 247-277.

Halfmeier A., Sonder N., [w:] Rome Regulations: Commentary on the European Rules of the Conflict of Laws, red. G. Calliess, Alphen aan den Rijn 2011.

Heiderhoff B., Eine europäische Kollisionsnorm für die Produkthaftung: Gedanken zur Rom II - Verordnung, «GPR» 2/2005, s. 92-97.

Hibbert M., New EU choice of law rules for tort and product liability claims finalised, «European Product Liability Review» 9/2007, s. 12-14.

Hoy ER H., Haager Straßenverkehrsübereinkommen und Rechtswahl der Parteien, «ZfRV» 1991, s. 341-348.

Huber P., Illmer M., International Product Liability. A Commentary on Article 5 of The Rome II Regulation, «YPIL» 9/2007, s. 31-49.

Illmer M., The New European Private International Law of Product Liability - Steering Through Troubled Waters, «RabelsZ»73/2009, s. 269-313.

Jagielska M., Prawo właściwe dla odpowiedzialności za produkt - rozważania na tle projektu rozporzadzenia WE o prawie właściwym dla zobowiązań pozaumownych, [w:] Rozprawy prawnicze. Ksiegga pamiątkowa Profesora Maksymiliana Pazdana, red. L. OgIEgŁo, W. PopioŁek, M. SzPunar, Kraków 2005, s. 109-122.

Junker A., Das internationale Privatrecht der Straßenverkehrsunfälle nach der Rom II - Verordnung, «JZ» 4/2008, s. 169-179.

Kegel G., Schurig K., Internationales Privatrecht, München 2000.

KRZYMUSKi M., Wybór prawa właściwego dla pozaumownej odpowiedzialności cywilnej wynikającej z wypadków drogowych, [w:] Znad granicy ponad granicami. Ksiega dedykowana Profesorowi Dieterowi Martiny, Warszawa 2014, s. 133-150.

Kurki V., Pietrzykowski T. (red.), Legal Personhood: Animals, Artificial Intelligence and the Unborn, Cham 2017.

MARCHAND G., LINDOR R., The coming collision between autonomous vehicles and the liability system, «Santa Clara Law Review» 52/2012, s. 1321-1340.

Nagy C., The Rome II Regulation and Traffic Accidents: Uniform Conflict Rules with some Room for forum shopping - how so?, «PIL» 6.1/2010, s. 93-108.

Nevejans N., Traité de droit et d'éthique de la robotique civile, Bordeaux 2017. 
Ofner H., Die Rom II - Verordnung - Neues Internationales Privatrecht für außervertragliche Schuldverhältnisse in der Europäischen Union, «ZfRV»1/2008, s. 13-24.

PAJOR T., Comments on a preliminary draft proposal for a Council Regulation on the law applicable to non-contractual obligations, Łódź 2002.

PAZDAN J., Rozporzadzenie Rzym II - nowe wspólnotowe unormowanie właściwości prawa dla zobowiązań pozaumownych, „Problemy Prawa Prywatnego Międzynarodowego" 4/2009, s. 13-36.

Pazdan J., Zachariasiewicz M.-A., Pazdan M., Świerczý́ski M., ZachaRIASIEWICZ M., Kurowski W., PACUŁA K., Uwagi o uregulowaniach rozporządzenia Rzym II i ich stosowaniu na tle doświadczeń polskiej judykatury, «Problemy Prawa Prywatnego Międzynarodowego» 16/2017, s. 67-93.

Pazdan M. (red.), Prawo prywatne międzynarodowe. Komentarz, Warszawa 2018.

PAZDAn M. (red.), System prawa prywatnego. Prawo prywatne międzynarodowe, Warszawa 2014.

Pazdan M., Jagielska M., Kurowski W., Świerczyński M., ZaChariaSIEWICZ A.-M., ZACHARIASIEWICZ M., ŻARNowieC Ł., W odpowiedzi na ankietę skierowana do państw członkowskich Unii, dotycząca stosowania Rozporządzenia $n r$ 864/2007 o prawie właściwym dla zobowiązań pozaumownych (Rzym II), «Problemy Prawa Prywatnego Międzynarodowego» 12/2013, s. 165-197.

Pietrzy kowski T., Personhood Beyond Humanism Animals, Chimeras, Autonomous Agents and the Law, Cham 2018.

Plender R., Wilderspin M., The European Private International Law of Obligations, London 2009.

Rauscher T. (red.), Europäisches Zivilprozess- und Kollisionsrecht EuZPR/ EUIPR Kommentar, München 2011.

Rufener A., Honsell H., Vogt N., Schnyder A., Berrti S., Basler Kommentar. Internastionales Privatrecht, Basel 2007.

Sprawozdanie Komisji „Ratowanie życia: zwiększanie bezpieczeństwa samochodowego w UE" (COM(2016) 0787 final).

Staudinger A., Czaplinski P., Verkehrsopferschutz im Lichte der Rom I-, Rom II- sowie Brüssel I-Verordnung, «NJW» 3/2009, s. 2249-2254.

Stone P., Brooks R., Brynjolfsson E., Calo R., Etzioni O., Hager G., Hirschberg J., Kalyanakrishnan S., Kamar E., Kraus S., Leyton-Brown K., Parkes D., Press W., Saxenian A., Shah J., Tambe M., TelLER A., Artificial Intelligence and Life in 2030. One Hundred Year Study 
on Artificial Intelligence: Report of the 2015-2016 Study Panel, Stanford University, September 2016, https://ai100.stanford.edu/sites/default/files/ ai100report10032016fnl_singles.pdf, s. 19, dostęp: 7 stycznia 2019 r.

Stone P., Product Liability under the Rome II Regulation, [w:] The Rome II Regulation on the Law Applicable to Non-Contractual Obligations, red. J. Ahern, W. Binchy, Leiden-Boston 2009, s. 175-197.

Stone P., The Rome II Regulation On Choice Of Law In Tort, "Ankara Law Review» 2/2007, s. 95-130.

Symonides S., Rome II and Tort Conflicts: A Missed Opportunity?, «AmJCL» 2008, s. 173-222.

Verschraegen B., Internationales Privatrecht, Wien 2012.

Von Hein J., Article 4 and Traffic Accidents, [w:] The Rome II Regulation on the Law Applicable to Non-Contractual Obligations, red. J. AHern, W. BINCHY, Leiden-Boston 2009, s. 153-173.

Von Hein J., Europäisches Internationales Deliktsrecht nach der Rom II - Verordnung, "Zeitschrift für Europäisches Privatrecht» 1/2009, s. 6-33.

Von HeIn J., Of Older Siblings and Distant Cousins: The Contribution of the Rome II Regulation to the Communitarisation of Private International Law, «RabelsZ» 73/2009, s. 461-508.

Żarnowiec Ł., Prawo właściwe dla odpowiedzialności za szkodę wyrządzona przez produkt niebezpieczny w świetle przepisów rozporządzenia Rzym II, «PPPM» 5/2009, s. 87-113.

ŻARNOWIEC Ł., Przepisy wymuszajace swoje zastosowanie $w$ świetle rozporzadzenia Parlamentu Europejskiego i Rady (WE) nr 864/2007 z dnia 11 lipca 2007 r. o prawie właściwym dla zobowiązań pozaumownych - „Rzym II”, [w:] Państwo i prawo $w$ dobie globalizacji. Ksiega jubileuszowa, red. S. SAGAN, Rzeszów 2011, s. 340-355. 